\title{
MODEL PEMBELAJARAN DISCOVERY LEARNING BERBANTUAN SUBAK SEBAGAI SUMBER BELAJAR TERHADAP LITERASI EKOLOGIS DAN HASIL BELAJAR IPS
}

\author{
S.Lestari ${ }^{1}$, I.P. Sriartha ${ }^{2}$, I.B.M. Astawa ${ }^{3}$ \\ ${ }^{123}$ Program Studi Pendidikan IPS,Universitas Pendidikan Ganesha, Singaraja \\ e-mail: sestulestari14@gmail.com¹, putusriartha@gmail.com², idabagusmadeastawa@yahoo.com³
}

\begin{abstract}
Abstrak
Penelitian ini bertujuan untuk menganalisis perbedaan literasi ekologis dan hasil belajar antara siswa yang mengikuti pembelajaran model discovery learning berbantuan subak sebagai sumber belajar dengan siswa yang mengikuti pembelajaran model konvensional, baik secara parsial maupun simultan. Penelitian dilakukan di kelas VIII SMP Negeri 4 Singaraja pada tahun ajaran 2019/2020. Populasi penelitian berjumlah sebelas kelas dengan total siswa 352 orang. Sampel penelitian adalah kelas VIII B3 yang dipilih secara random sampling setelah dilakukan uji kesetaraan kelas. Data dikumpulkan dengan teknik observasi dan tes. Analisis data dilakukan dengan teknik statistik inferensial, yaitu analisis Manova. Hasil penelitian menunjukkan bahwa: (1) terdapat perbedaan literasi ekologis antara siswa yang mengikuti model discovery learning berbantuan subak sebagai sumber belajar dengan siswa yang mengikuti model pembelajaran konvensional dengan Fhitung $=19,397(p<0,05)$, (2) terdapat perbedaan hasil belajar IPS antara siswa yang mengikuti model discovery learning berbantuan subak sebagai sumber belajar dengan siswa yang mengikuti model pembelajaran konvensional dengan Fhitung $=86,899(p<0,05)$, dan $(3)$ terdapat perbedaan literasi ekologis dan hasil belajar IPS secara simultan antara siswa yang mengikuti model discovery learning berbantuan subak sebagai sumber belajar dengan siswa yang mengikuti model pembelajaran konvensional dengan FWilks' Lambda $=1024,079(\mathrm{p}<0,05)$. Implikasi penelitian adalah perlu reorientasi penggunaan model pembelajaran konvensional ke arah model pembelajaran inovatif seperti discovery learning dan mengoptimalkan pemanfaatan lingkungan lokal sebagai sumber pembelajaran IPS.
\end{abstract}

Kata kunci: Hasil Belajar IPS; Literasi Ekologis; Model Discovery Learning, Subak

\begin{abstract}
This study was aimed at analyzing the differences in ecological literacy and social studies learning achievement between students taught by using the discovery learning model with subak (Balinese traditional water management for rice fields) as a learning resource and those taught by using the conventional model both partially or simultaneously. The research was carried out to the ninth graders of SMP Negeri 4 Singaraja in the academic year 2019-2020. The population of the study comprised eleven classes with a total of 352 students. The research sample was class VIII B3 selected by using random sampling after the class equality test was carried out. The data were collected through observation and testing techniques and the data analysis was conducted by using the Manova statistical analysis. The results showed that: (1) there was a difference in the ecological literacy between the students taught by using the discovery learning model assisted with subak as a learning resource and those taught by using the conventional model with an Fcount being 19.397 ( $p<$ 0.05); (2) there was a difference in the social studies learning achievement between the students taught by using the discovery learning model assisted with subak as a learning resource and those taught by using the conventional model with an Fcount being $86.899(p<0.05)$; and (3) there was a difference in the ecological literacy and social studies learning achievement simultaneously between the students taught by using the discovery learning model assisted with subak as a learning resource and those taught by using the conventional model with an FWilks'Lambda being $1024.079(p<0.05)$. The research implication suggests that social studies teachers need to reorient the use of conventional learning models towards innovative learning models such as discovery learning and to optimize the use of the local environment as a resource in social studies learning activities.
\end{abstract}

Keywords: social studies achievement; ecological literacy; discovery learning model, subak 


\section{PENDAHULUAN}

Pembelajaran IPS hakikatnya bertujuan agar pembelajaran menjadi lebih bermakna bagi siswa, sehingga pengorganisasian materi atau bahan ajar disesuaikan dengan lingkungan, karakteristik, dan kebutuhan peserta didik itu sendiri. Melalui pembelajaran yang bermakna diharapkan agar peserta didik dapat hidup bermasyarakat dengan baik serta dapat memecahkan masalah-masalah pribadi dan masalah-masalah sosial.Guna dapat mewujudkan tujuan tersebut, siswa perlu dibekali tidak saja dengan knowledge (pengetahuan) dan skill (keterampilan), tetapi juga dengan attitudes (sikap), values (nilai) dan action (tindakan).

Masalah-masalah sosial yang dihadapi siswa dalam kehidupan sehari-hari harus menjadi bagian dari materi pembelajaran IPS sehingga mereka dapat memahami, menyadari, dan memiliki keterampilan dalam memecahkan masalah-masalah sederhana yang dihadapinya. Literasi ekologis peserta didik bisa menjadi salah satu alat untuk memecahkan masalah sederhana dalam dunia nyata mereka. Literasi ekologis yang dimiliki seorang individu didasari atas pengetahuan, kesadaran, dan keterampilan hidup selaras dengan kelestarian alam. Konsep literasi ekologis memiliki kesamaan makna dengan kecerdasan ekologis. Seseorang yang cerdas secara ekologis adalah orang yang memahami bahwa setiap perilaku dan tindakannya tidak hanya berdampak pada dirinya dan orang lain melainkan juga pada lingkungan alam tempat dia tinggal. Kecerdasan tersebut dibangun oleh pemahaman bahwa alam tempat dia tinggal harus dijaga agar tetap memliki daya dukung bagi kehidupan dirinya dan orang lain. Oleh karena itu, berdasarkan pemahaman tersebut, seseorang yang memiliki kecerdasan ekologis akan menyadari bahwa alam tempat semua mahluk hidup berada harus dijaga kelestariannya agar semua mahluk hidup, termasuk manusia, dapat meneruskan dan meningkatkan kehidupannya menjadi lebih baik di planet ini. Hal ini sejalan dengan pilar kelima pembelajaran UNESCO (learning to live sustanabilities).

Perkembangan perekonomian telah memberikan tekanan ekologis yang semakin besar pada Bali sebagai ekologi pulau kecil. Hal tersebut berpotensi merusak lingkungan dibandingkan pelestarian alam dan sumber daya (Astawa, 2015). Apabila pemahaman dan kesadaran tentang pentingnya menjaga, merawat, melestarikan alam serta berhubungan baik dengan mahluk hidup di alam kurang dimiliki seseorang maka dia akan melakukan tindakan-tindakan yang tidak selaras dengan kelestarian alam. Kecerdasan ekologis menggambarkan kemampuan atau kapasitas seseorang dalam melakukan tindakan yang terkait dengan aspek ekologis, yaitu pelestarian alam (Supriatna, 2017:24).

Sejalan dengan itu, dalam IPS diperlukan pembelajaran di luar ruangan karena laboratorium IPS adalah masyarakat dan lingkungan, sehingga pembelajaran IPS erat kaitannya dengan kearifan lokal yang ada di masyarakat. Salah satu kearifan lokal yang ada di Bali adalah Subak. Dalam kehidupan masyarakat Hindu di Bali, subak adalah salah satu unit kesatuan sosial yang berkembang di masyarakat, selain desa, banjar dan sekehe dengan tugas dan fungsi masing-masing. Pemaknaan tentang subak dapat mengacu pada ketentuan Perda Bali No.02/PD/DPRD/1972 yang mengatakan bahwa "Subak merupakan masyarakat hukum adat yang bersifat sosio-religius yang secara historis didirikan sejak dulu, dan berkembang terus sebagai organisasi penguasa tanah dalam bidang pengaturan air dan lain-lain untuk persawahan dari satu sumber air dalam suatu daerah". Batasan ini dikritisi Pitana (2007) dengan mengatakan bahwa subak sebagaimana dimuat pada Perda Bali tersebut, belum sepenuhnya tepat, sebab pada kenyataannya satu sumber air bisa dimanfaatkan oleh beberapa subak, dan sebaliknya bisa jadi satu subak mendapatkan air dari beberapa sumber. Subak juga berperan sentral sebagai penyangga budaya dan lingkungan Bali serta menjadi sumber atau "roh" berkembangnya sektor pariwisata seperti sekarang (Sriartha dan Windia, 2015).

Keterlibatan peserta didik dalam proses belajar mengajar harus secara totalitas, artinya peserta didik dalam pembelajaran melibatkan pikiran, penglihatan, pendengaran, dan psikomotor. Jadi, dalam proses belajar mengajar seorang guru harus mengajar siswa untuk aktif dalam mengikuti pelajaran. Dalam proses belajar mengajar guru menjadi pemeran 
utama dalam menciptakan situasi interaksi yang edukatif, yakni interaksi antara guru dengan siswa, siswa dengan siswa dan dengan sumber pembelajaran dalam menunjang tercapainya tujuan belajar. Widyaasrini (2015:7) menyatakan permasalahan-permasalahan riil yang ada di lapangan mencakup tiga hal, yaitu (1) mata pelajaran IPS cenderung dianggap sebagai mata pelajaran yang kurang penting sehingga membosankan, alasannya karena materi pembelajarannya bersifat hafalan, sehingga mata pelajaran ini semakin membosankan; (2) Kegiatan proses pembelajaran selama ini cenderung hanya menekankan pada aspek koqnitif saja, sementara aspek efektif dan psikomotornya dianggap sangat sulit untuk diaplikasikan, selain itu guru atau tenaga pendidik cenderung hanya mencapai target materi kurikulum saja, lebih penting pada penghafalan daripada pemahaman konsep; dan (3) Strategi, metode, pendekatan atau model pembelajaran yang digunakan bersifat konvensional. Hal yang sama juga dikemukakan oleh Asri (2015) melalui hasil penelitiannya di SMPN 2 Banjar menyatakan permasalahan yang terjadi di dalam kelas, yaitu cara mengajar guru cenderung menetapkan metode pembelajaran konvensional (ceramah) dengan sedikit sekali metode tanya jawab dan diskusi. Guru belum mampu memilih dan mengembangkan model pembelajaran yang mampu merangsang siswa untuk belajar. Siswa hanya mengandalkan catatan yang mereka peroleh pada saat guru menjelaskan materi ajar, sehingga wawasan mereka menjadi rendah.Pertanyaaanpun sebagian dari guru bukan dari siswa, oleh sebab itu siswa merasa bosan mendengarkannya.

Materi yang diajarkan dalam pembelajaran IPS cenderung hanya berupa sajian konsep yang terdapat dalam buku ajar atau LKS sehingga, pengetahuan siswa cenderung hanya sebatas materi yang terdapat pada buku LKS.Pembelajaran IPS yang diterapkan di sekolah terkesan masih kaku, kurang fleksibel, berisi hafalan dan membosankan bagi siswa. Sebagian siswa menganggap mata pelajaran IPS sebagai mata pelajaran yang sulit dipahami sehingga, siswa cenderung merasa bosan, jenuh dan malas untuk belajar, siswa kurang termotivasi karena siswa menganggap mata pelajaran IPS merupakan mata pelajaran yang bersifat hafalan, sehingga motivasi siswa menurun yang mengakibatkan rendahnya hasil belajar siswa.

Roestiyah (2004:57) menyatakan bahwa model pembelajaran konvensionalyang mengedepankan metode ceramah memiliki kelemahan-kelemahan, yaitu (1) mudah menjadi verbalisme (sebatas pengertian kata-kata), (2) pemahaman visual cenderung berkurang karena kemampuan auditif lebih berperan dalam menangkap materi pembelajaran, (3) apabila terlalu lama diterapkan akan menjadi membosankan, (4) guru menyimpulkan bahwa siswa mengerti dan tertarik pada ceramah yang disampaikan padahal siswa mengalami kesulitan dalam belajar, (5) kadangkala pengertian siswa menyimpang dari keterangan guru tentang materi tertentu, (6) menjadikan siswa pasif dalam proses pembelajaran, (7) tidak memberi kesempatan berkembangnya aktifitas serta ekspresi secara mandiri, dan (8) siswa memiliki kecenderungan untuk menghafal materi yang dijelaskan guru.

Beberapa kelemahan model konvensional tersebut akan berpengaruh pada rendahnya hasil belajar siswa dan pembelajaran cenderung menjadi membosankan. Hasil belajar yang rendah disebabkan oleh beberapa hal, yakni ketersediaan prasarana, motivasi belajar siswa rendah dan model pembelajaran yang belum tepat.Pola pengajaran guru yang masih menggunakan cara-cara yang konvensional dengan hanya mengandalkan metode ceramah yangakan membuat proses pembelajaran menjadi tidak bermakna dan monoton, sehingga apa yang diberikan oleh guru tersebut tidak bertahan lama dalam memori siswa. Pembelajaran bermakna akan dapat mengarahkan agar siswa mampu mengaplikasikan pengetahuan yang dimiliki ke dalam kehidupan sehari-hari.

Solusi yang ditawarkan untuk menjawab permasalahan yang ada di lapangan adalah dengan menerapkan model pembelajaran Discovery learning. Bruner (1961) menyatakan pengertian discovery learning adalah metode belajar yang mendorong siswa untuk mengajukan pertanyaan dan menarik kesimpulan dari prinsip-prinsip umum praktis contoh pengalaman. Ide dasar pemikiranJ. Bruner ialah pendapat dari Piaget yang menyatakan bahwa anak harus berperan secara aktif didalam belajar di kelas. Untuk itu Bruner memakai cara dengan apa yang disebutnya discovery learning, yaitu pembelajaran yang memposisikan siswauntuk mengorganisasikan bahan yang dipelajari dengan suatu bentuk 
akhir. Menurut Bell (1978), belajar penemuan adalah belajar yang terjadi sebagai hasil dari siswa memanipulasi, membuat struktur dan mentransformasikan informasi sedemikian sehingga bisa menemukan informasi baru. Dalam belajar penemuan, siswa dapat membuat perkiraan, merumuskan suatu hipotesis dan menemukan kebenaran dengan menggunakan prose induktif atau proses dedukatif, melakukan observasi dan membuat ekstrapolasi.

Joolingen (dalam Rohim, dkk., 2012:2) menjelaskan bahwa discovery learning adalah suatu tipe pembelajaran dimana siswa membangun pengetahuan mereka sendiri dengan mengadakan suatu percobaan dan menemukan sebuah prinsip dari hasil percobaan tersebut. Discoverylearning merupakan komponen dari praktik pendidikan yang meliputi metode mengajar yang memajukan cara belajar aktif, berorientasi pada proses, mengarahkan sendiri dan reflektif (Suryosubroto, 2002:192). Sementara menurut Rohani (2004:37) mengatakan bahwa dalam discovery para peserta didik diharuskan menemukan prinsip atau hubungan yang sebelumnya tidak diketahuinya yang merupakan akibat dari pengalaman belajarnya yang telah diatur secara cermat dan seksama oleh guru.

Penerapan model pembelajaran discovery learning di SMP terutama pada mata pelajaran IPS menjadi sangat tepat sebagai solusi mengatasi permasalahan dari keterbatasan model pembelajaran konvensional dalam mengembangkan kemampuan literasi ekologis dan hasil belajar IPS siswa. Oleh karena itu, peneliti termotivasi untuk melaksanakan penelitian dengan judul "Pengaruh Model Pembelajaran Discovery Learning Berbantuan Subak Sebagai Sumber Belajar Terhadap Literasi Ekologis dan Hasil Belajar IPS Siswa SMP Negeri 4 Singaraja."

\section{METODE}

Penelitian ini menggunakan rancangan kuasi eksperimen. Rancangan ini dipilih karena eksperimen dilakukan di beberapa kelas tertentu dengan siswa yang telah ada atau sebagaimana adanya. Rancangan eksperimen yang dipilih adalah rancangan NonEquivalent Post-Test Only Control Group Design. Populasi dalam penelitian ini adalah seluruh siswa kelas VIII SMP Negeri 4 Singaraja pada tahun ajaran 2019/2020, dengan jumlah 352 orang yang tersebar dalam sebelas kelas pararel. Hasil uji kesetaraan menunjukkan bahwa dari 11 kelas yang ada, terdapat 10 kelas yang memiliki kesetaraan dalam hal hasil belajar IPS. Berdasarkan hasil kesetaraan kelas VIII SMP Negeri 4 Singaraja memiliki kemampuan yang setara maka bisa dilakukan dengan random sampling terhadap 10 kelas. Dua kelas dijadikan sampel penelitian, satu kelas sebagai kelas eksperimen dan satu kelas sebagai kelas kontrol. Data dikumpulkan dengan tes literasi ekologis dan tes hasil belajar IPS serta dianalisis dengan teknik statistic manova.

\section{HASIL DAN PEMBAHASAN}

Hipotesis pertama yang diajukan dalam penelitian ini adalah terdapat perbedaan yang signifikan literasi ekologis antara siswa yang belajar menggunakan model discovery learning berbantuan subak sebagai sumber belajar dengan siswa yang belajar menggunakan model pembelajaran konvensional pada siswa SMP Negeri 4 Singaraja. Pengujian hipotesis pertama menggunakan hasil analisis univariat pada Manova. Hipotesis yang diuji secara statistik adalah $\mathrm{H}_{0}$. Kriteria penolakan $\mathrm{H}_{0}$ jika harga $\mathrm{F}$ memiliki angka signifikansi lebih kecil dari 0,05. Rekapitulasi hasil analisis varian satu jalur disajikan pada Tabel 1.

Tabel 1. Rekapitulasi Hasil Analisis Varian Satu Jalur untuk Literasi Ekologis

\begin{tabular}{lccccc}
\hline & Sum of Squares & $d f$ & Mean Square & $F$ & Sig. \\
\hline Between Groups & 276,391 & 1 & 276,391 & 19,397 & 0,000 \\
Within Groups & 883,469 & 62 & 14,249 & & \\
Total & 1159,859 & 63 & & & \\
\hline
\end{tabular}

Berdasarkan rekapitulasi hasil analisis varian satu jalur yang disajikan pada Tabel 1 dapat ditunjukkan bahwa nilai $F=19,397(p<0,05)$, sehingga $H_{0}$ yang menyatakan tidak terdapat perbedaan yang signifikan literasi ekologis antara siswa yang belajar menggunakan model discovery learning berbantuan subak sebagai sumber belajar dengan siswa yang 
belajar menggunakan model pembelajaran konvensional pada siswa SMP Negeri 4 Singaraja ditolak. Jadi, terdapat perbedaan yang signifikan literasi ekologis antara siswa yang belajar menggunakan model discovery learning berbantuan subak sebagai sumber belajar dengan siswa yang belajar menggunakan model pembelajaran konvensional pada siswa SMP Negeri 4 Singaraja.

Hipotesis kedua yang diajukan dalam penelitian ini adalah terdapat perbedaan yang signifikan hasil belajar IPS antara siswa yang belajar menggunakan model discovery learning berbantuan subak sebagai sumber belajar dengan siswa yang belajar menggunakan model pembelajaran konvensional pada siswa SMP Negeri 4 Singaraja. Pengujian hipotesis kedua menggunakan hasil analisis univariat pada Manova. Hipotesis yang diuji secara statistik adalah $\mathrm{H}_{0}$. Kriteria penolakan $\mathrm{H}_{0}$ jika harga $\mathrm{F}$ memiliki angka signifikansi lebih kecil dari 0,05. Rekapitulasi hasil analisis varian satu jalur disajikan pada Tabel 2.

Tabel 2. Rekapitulasi Hasil Analisis Varian Satu Jalur untuk Hasil Belajar IPS

\begin{tabular}{lccccc}
\hline & Sum of Squares & $d f$ & Mean Square & $F$ & Sig. \\
\hline Between Groups & 5719,141 & 1 & 5719,141 & 86,899 & 0,000 \\
Within Groups & 4080,469 & 62 & 65,814 & & \\
Total & 9799,609 & 63 & & & \\
\hline
\end{tabular}

Berdasarkan rekapitulasi hasil analisis varian satu jalur yang disajikan pada Tabel 2 dapat ditunjukkan bahwa nilai $F=86,899(p<0,05)$, sehingga $\mathrm{H}_{0}$ yang menyatakan tidak terdapat perbedaan yang signifikan hasil belajar IPS antara siswa yang belajar menggunakan model discovery learning berbantuan subak sebagai sumber belajar dengan siswa yang belajar menggunakan model pembelajaran konvensional pada siswa SMP Negeri 4 Singaraja ditolak. Jadi, terdapat perbedaan yang signifikan hasil belajar IPS antara siswa yang belajar menggunakan model discovery learning berbantuan subak sebagai sumber belajar dengan siswa yang belajar menggunakan model pembelajaran konvensional pada siswa SMP Negeri 4 Singaraja.

Hipotesis ketiga yang diajukan dalam penelitian ini adalah terdapat perbedaan yang signifikan literasi ekologis dan hasil belajar IPS secara simultan antara siswa yang belajar menggunakan model discovery learning berbantuan subak sebagai sumber belajar dengan siswa yang belajar menggunakan model pembelajaran konvensional pada siswa SMP Negeri 4 Singaraja. Pengujian hipotesis ketiga dengan manova satu jalur. Hipotesis yang diuji secara statistik adalah $\mathrm{H}_{0}$. Kriteria penolakan $\mathrm{H}_{0}$ jika taraf signifikansi untuk statistik Wilks' Lambda lebih kecil dari 0,05. Rekapitulasi hasil hasil uji Manova satu jalur tersaji pada Tabel 3.

Tabel 3. Rekapitulasi Hasil Manova Satu Jalur

\begin{tabular}{lccccc}
\hline \multicolumn{1}{c}{ Effect } & Value & $F$ & Hypothesis df & Error df & Sig. \\
\hline Pillai's Trace & 0,971 & 1024,079 & 2,000 & 61,000 & 0,000 \\
Wilks' Lambda & 0,029 & 1024,079 & 2,000 & 61,000 & 0,000 \\
Hotelling's Trace & 33,576 & 1024,079 & 2,000 & 61,000 & 0,000 \\
Roy's Largest Root & 33,576 & 1024,079 & 2,000 & 61,000 & 0,000 \\
\hline
\end{tabular}

Berdasarkan ringkasan analisis manova satu jalur yang disajikan pada Tabel 3 , dapat diinterpretasikan bahwa taraf signifikansi untuk nilai F-Wilks' Lambda $=1024,079(p<0,05)$, sehingga $\mathrm{H}_{0}$ yang menyatakan tidak terdapat perbedaan yang signifikan literasi ekologis dan hasil belajar IPS secara simultan antara siswa yang belajar menggunakan model discovery learning berbantuan subak sebagai sumber belajar dengan siswa yang belajar menggunakan model pembelajaran konvensional pada siswa SMP Negeri 4 Singaraja ditolak. Jadi, terdapat perbedaan yang signifikan literasi ekologis dan hasil belajar IPS secara simultan antara siswa yang belajar menggunakan model discovery learning berbantuan subak sebagai sumber belajar dengan siswa yang belajar menggunakan model pembelajaran konvensional pada siswa SMP Negeri 4 Singaraja. 
Untuk permasalahan pertama,hasil analisis dengan analisis varians satu jalur diperoleh bahwa nilai $F=19,397(p<0,05)$. Oleh karena itu, hipotesis nol $\left(H_{0}\right)$ yang menyatakan bahwa tidak terdapat perbedaan yang signifikan literasi ekologis antara siswa yang belajar menggunakan model discovery learning berbantuan subak sebagai sumber belajar dengan siswa yang belajar menggunakan model pembelajaran konvensional pada siswa SMP Negeri 4 Singaraja ditolak. Jadi, terdapat perbedaan yang signifikan literasi ekologis antara siswa yang belajar menggunakan model discovery learning berbantuan subak sebagai sumber belajar dengan siswa yang belajar menggunakan model pembelajaran konvensional pada siswa SMP Negeri 4 Singaraja.

Hasil analisis deskriptif menunjukkan bahwa perbedaan literasi ekologis siswa yang mengikuti model discovery learning berbantuan subak sebagai sumber belajar dengan skor rata-rata 25,63, sedangkan literasi ekologis siswa yang mengikuti model pembelajaran konvensional dengan skor rata-rata 21,47. Ternyata skor rata-rata literasi ekologis siswa yang mengikuti model discovery learning berbantuan subak sebagai sumber belajar lebih tinggi daripada siswa yang mengikuti model pembelajaran konvensional.Dengan demikian, dapat disimpulkan literasi ekologis siswa yang mengikuti model discovery learning berbantuan subak sebagai sumber belajar lebih unggul daripada siswa yang mengikuti model pembelajaran konvensional.

Discovery learning merupakan komponen dari praktik pendidikan yang meliputi metode mengajar yang memajukan cara belajar aktif, berorientasi pada proses, mengarahkan sendiri dan reflektif (Suryosubroto, 2002). Dalam discovery learning peserta didik diharuskan menemukan prinsip atau hubungan yang sebelumnya tidak diketahuinya yang merupakan akibat dari pengalaman belajarnya yang telah diatur secara cermat dan seksama oleh guru (Rohani (2004).Karakteristik model discovery learning merupakan sebuah keunggulan dibandingkan denganmodel pembelajaran yang lain dalam rangka mencapai tujuan pembelajaran untuk meningkatkan literasiekologi. Hal ini disebabkan aspek dari literasi ekologi bersesuaian dengan karakteristik model discovery learning. Aspek penyusunyang tercakup dalam literasi ekologi adalah aspek pemahaman konsep ekologis, kepedulian dan sikap (Orr, 1992). Tujuan spesifik dari pembelajaran dengan model pembelajaran discovery learning adalah terdapat beberapa fakta yang menunjukan bahwa keterampilanketerampilan, konsep-konsep dan prinsip-prinsip yang dipelajarimelalui penemuan lebih bermakna (Hosnan, 2014).

Siswa melakukan kegiatan penyelidikan seperti mencari informasi dari referensi, merencanakanpenyelesaian masalah, menyelesaikan masalah, dan memeriksa kembali hasil pekerjaannya. Kegiatanpenyelidikan/mencari informasi dan menyelesaikan masalah akan membuat kemampuan siswa pada aspek pemahaman konsep ekologis akan berkembang (Nugroho dkk., 2018). Solusi yang diberikan siswa dalam penyelesaian masalah dapat mengasah kemampuan siswa pada aspek sikap. Semua proses tersebut dapat mengakibatkan siswa berperan aktif dalam pembelajaran sehingga kemampuan literasi ekologi siswa berkembang dengan baik. Dalam rangka menjaga kelestarian lingkungan, setiap individu seharusnya memiliki kemampuan literasi ekologi yang mumpuni, kemampuan literasi ekologi tersebut dapat ditingkatkan melalui pembelajaran penemuan (Lewinshon, 2014).

Literasi ekologi juga bersesuaian dengan karakteristik subak sebagai sumber belajar. Aspek penyusun yang tercakup dalam literasi ekologi adalah aspek pemahaman konsep ekologis, kepedulian dan sikap erat kaitannya dengan kearifan lokal subak yang ada di masyarakat. Adanya sistem subak merangsang peserta didik untuk berpartisipasi secara aktif terlibat dalam membangunbentuk pengetahuan, solusi, komunikasi,dan pengambilan keputusan (Surata dkk., 2014). Sistem subak memiliki kekuatan internal atau kejeniusan lokal yang disebut filosofi Tri Hita Karana. Komponen parhyangan adalah perwujudan kearifan budaya, komponen pawongan adalah perwujudan kearifan sosial dan ekonomi dan komponen palemahan adalah perwujudan kearifan teknologi dan ekologi (Sriartha dan Giyarsih, 2015). Komponen palemahan mengatur hubungan harmonis antara manusia dan lingkungan alam (Sriartha dan Kertih, 2019). Berdasarkan pendapat tersebut, komponen palemahan dapat meningkatkan pemahaman ekologi siswa dan kepedulian siswa terhadap 
kelestarian lingkungan serta dapat bersikap yang baik untuk mencegah kesusakan lingkungan. Dengan demikian, kearifan lokal subak sebagai sumber belajar dapat mengembangkan literasi ekologis siswa secara maksimal.

Berbeda dengan dalam pembelajaran IPS dengan menggunakan pembelajaran konvensional, lebih menekankan pada fungsi guru sebagai pemberi informasi.Siswa hanya pasif mendengarkan penjelasan guru tanpa dilibatkan secara aktif dalam pembelajaran. Guru lebih cenderung menyampaikan materi pelajaran satu arah (teacher centered). Pembelajaran yang bersifat teacher centered akan sangat sulit untuk mengembangkan keaktifan siswa, sehingga kemampuan literasi ekologi siswa pun akan cenderung kurang maksimal untuk ditingkatkan (Nugroho dkk., 2018).

Secara empiris, hasil penelitian ini didukung oleh hasil penelitian terdahulu yang dilakukan oleh Maryama dkk. (2018) menunjukkan bahwa discovery learning meningkatkan pemahaman konsep ekologi siswa.Literasi lingkungan siswa SMA berdasarkan hasil penelitian angket attitude dan knowledge menunjukkan hasil yang baik, sehingga layak sebagai perangkat pembelajaran untuk meningkatkan literasi lingkungan.Penelitian yang dilakukan oleh Mantaka (2018) menunjukkan bahwa perlunya upaya untuk melestarikan nilai-nilai kearifan lokal subak yang kita miliki karena nilai-nilai yan dimiliki memiliki makna yang cukup tinggi yaitu pesan moral tentang ideologi hijau untuk selalu menjaga kelestarian lingkungan dan pesan humanis untuk selalu menjaga keharmonisan atau kerjasama antar anggota masyarakat, sesuai filosofi Tri Hita Karana sehingga pantas untuk dijadikan sebagai sumber belajar dalam pembelajaran IPS.

Hasil penelitian seperti yang disebutkan di atas tampak bahwa model discovery learning berbantuan subak sebagai sumber belajar berpengaruh terhadap literasi ekologis siswa. Dengan demikian dapat disimpulkan bahwa terdapat perbedaan yang signifikan literasi ekologis antara siswa yang belajar menggunakan model discovery learning berbantuan subak sebagai sumber belajar dengan siswa yang belajar menggunakan model pembelajaran konvensional pada siswa SMP Negeri 4 Singaraja terbukti secara teoretis dan empiris.

Untuk permasalahan kedua,hasil analisis dengan analisis varians satu jalur diperoleh bahwa nilai $F=86,899(p<0,05)$. Oleh karena itu, hipotesis nol $\left(\mathrm{H}_{0}\right)$ yang menyatakan bahwa tidak terdapat perbedaan yang signifikan hasil belajar IPS antara siswa yang belajar menggunakan model pembelajaran discovery learning berbantuan subak sebagai sumber belajar dengan siswa yang belajar menggunakan model pembelajaran konvensional pada siswa SMP Negeri 4 Singaraja ditolak. Jadi, terdapat perbedaan yang signifikan hasil belajar IPS antara siswa yang belajar menggunakan model discovery learning berbantuan subak sebagai sumber belajar dengan siswa yang belajar menggunakan model pembelajaran konvensional pada siswa SMP Negeri 4 Singaraja.

Hasil analisis deskriptif menunjukkan bahwa perbedaan hasil belajar IPS siswa yang mengikuti model discovery learning berbantuan subak sebagai sumber belajar dengan skor rata-rata 77,03, sedangkan hasil belajar IPS siswa yang mengikuti model pembelajaran konvensional dengan skor rata-rata 58,13. Ternyata skor rata-rata hasil belajar IPS siswa yang mengikuti model discovery learning berbantuan subak sebagai sumber belajar lebih tinggi daripada siswa yang mengikuti model pembelajaran konvensional. Dengan demikian, dapat disimpulkan hasil belajar IPS siswa yang mengikuti model discovery learning berbantuan subak sebagai sumber belajar lebih unggul daripada siswa yang mengikuti model pembelajaran konvensional.

Kelebihan dalam discovery learning siswa aktif dalam kegiatan belajar, sebab siswa berpikir dan menggunakan kemampuan untuk menemukan hasil akhir (Kristin dan Rahayu, 2016). Siswa memahami benar bahan pelajaran, sebab mengalami sendiri proses menemukannya. Sesuatu yang diperoleh dengan cara ini lebih lama diingat, proses menemukan sendiri menimbulkan rasa puas siswa.Pembelajaran dengan penemuan mendorong siswa untuk belajarmelalui keterlibatan secara aktif mereka sendiri dengan konsep-konsep dan prinsip-prinsip dan guru mendorong siswa untuk mengalami pengalaman yang memungkinkan mereka menemukan prinsip-prinsip untuk diri mereka sendiri (Hosnan, 2014). Dalam pelaksanaan model discovery aktivitas siswa belajar sendiri 
sangat berpengaruh dalam hasil belajar dengan model pembelajaran discovery (Krismanto, 2005).

Model discovery learning adalah proses mental dimana siswa mengasimilasi suatu konsep atau prinsip (Roestiyah, 2004). Proses mental tersebut misalnya mengamati, menggolongkan, membuat dugaan, menjelaskan, mengukur, membuat kesimpulan, dan sebagaimya. Dalam teknik ini siswa dibiarkan menemukan sendiri atau mengalami proses mental itu sendiri, guru hanya membimbing dan memberikan instruksi. Model discovery learning adalah model mengajar yang mengatur pengajaran sedemikian rupa sehingga anak memperoleh pengetahuan yang sebelumnya belum diketahuinya itu tidak melalui pemberitahuan, sebagian atau seluruhnya ditemukan sendiri. Dalam Model discovery learning kegiatan atau pembelajaran yang dirancang sedemikian rupa sehingga siswa dapat menemukan konsep-konsep dan prinsip-prinsip melalui proses mentalnya sendiri.Hal ini sangat penting dalam meningkatkan hasil belajar siswa.

Berbeda dengan pembelajaran IPS dengan menggunakan pembelajaran konvensional, siswa kurang mendapatkan kesempatan belajar dengan pengalaman sehari-hari.Dengan demikian, belajar IPS seolah-seolah belajar konsep-konsep atau prinsip-prinsip IPS yang tidak ada kaitannya dengan kehidupan anak. Oleh karena itu, pengetahuan anak tentang IPS sebatas pengetahuan yang ada pada buku serta apa yang diberikan oleh guru. Hal ini akan melemahkan semangat siswa untuk belajar, sehingga hasil belajar siswa tidak tercapai secara optimal.

Secara empiris, hasil penelitian ini didukung oleh hasil penelitian terdahulu yang dilakukan oleh Christy (2019) menunjukkan bahwa ada perbedaan yang signifikan hasil belajar IPS antara siswa yang belajar menggunakan model pembelajaran guided discovery learning dengan siswa yang belajar menggunakan model pembelajaran konvensional. Hasil juga menunjukkan model pembelajaran guided discovery learning lebih baik dibandingkan model pembelajaran konvensional dalam capaian hasil belajar IPS siswa.

Hasil penelitian seperti yang disebutkan di atas tampak bahwa model discovery learning berbantuan subak sebagai sumber belajar berpengaruh terhadap hasil belajar IPS siswa. Dengan demikian dapat disimpulkan bahwa terdapat perbedaan yang signifikan hasil belajar IPS antara siswa yang belajar menggunakan model discovery learning berbantuan subak sebagai sumber belajar dengan siswa yang belajar menggunakan model pembelajaran konvensional pada siswa SMP Negeri 4 Singaraja terbukti secara teoretis dan empiris.

Untuk permasalahan ketiga, hasil analisis dengan manova satu jalur tampak bahwa nilai F-Wilks' Lambda $=1024,079(p<0,05)$. Oleh karena itu, hipotesis nol $\left(H_{0}\right)$ yang menyatakan bahwa tidak terdapat perbedaan yang signifikan literasi ekologis dan hasil belajar IPS secara simultan antara siswa yang belajar menggunakan model discovery learning berbantuan subak sebagai sumber belajar dengan siswa yang belajar menggunakan model pembelajaran konvensional pada siswa SMP Negeri 4 Singaraja ditolak. Jadi, terdapat perbedaan yang signifikan literasi ekologis dan hasil belajar IPS secara simultan antara siswa yang belajar menggunakan model discovery learning berbantuan subak sebagai sumber belajar dengan siswa yang belajar menggunakan model pembelajaran konvensional pada siswa SMP Negeri 4 Singaraja.

Discovery learning merupakan komponen dari praktik pendidikan yang meliputi metode mengajar yang memajukan cara belajar aktif, berorientasi pada proses, mengarahkan sendiri dan reflektif (Suryosubroto, 2002). Dalam Model discovery learning peserta didik diharuskan menemukan prinsip atau hubungan yang sebelumnya tidak diketahuinya yang merupakan akibat dari pengalaman belajarnya yang telah diatur secara cermat dan seksama oleh guru (Rohani, 2004). Karakteristik pembelajaran dalam model discovery learning merupakan sebuah keunggulan dibandingkan dengan model pembelajaran yang lain dalam rangka mencapai tujuan pembelajaran untuk meningkatkan literasi ekologi. Hal ini disebabkan aspek dari literasi ekologi bersesuaian dengan karakteristik model discovery learning. Aspek penyusun yang tercakup dalam literasi ekologi adalah aspek pemahaman konsep ekologis, kepedulian dan sikap (Orr, 1992).Tujuan spesifik dari pembelajaran dengan model discovery learning adalah terdapat beberapa fakta yang menunjukan bahwa keterampilan- 
keterampilan, konsep-konsep dan prinsip-prinsip yang dipelajari melalui penemuan lebih bermakna (Hosnan, 2014).

Siswa melakukan kegiatan penyelidikan seperti mencari informasi dari referensi, merencanakan penyelesaian masalah, menyelesaikan masalah, dan memeriksa kembali hasil pekerjaannya. Kegiatan penyelidikan/mencari informasi dan menyelesaikan masalah akan membuat kemampuan siswa pada aspek pemahaman konsep ekologis akan berkembang (Nugroho dkk., 2018). Solusi yang diberikan siswa dalam penyelesaian masalah dapat mengasah kemampuan siswa pada aspek sikap. Semua proses tersebut dapat mengakibatkan siswa berperan aktif dalam pembelajaran sehingga kemampuan literasi ekologi siswa berkembang dengan baik. Dalam rangka menjaga kelestarian lingkungan, setiap individu seharusnya memiliki kemampuan literasi ekologi yang mumpuni, kemampuan literasi ekologi tersebut dapat ditingkatkan melalui pembelajaran penemuan (Lewinshon, 2015).

Kelebihan dalam discovery learning siswa aktif dalam kegiatan belajar, sebab siswa berpikir dan menggunakan kemampuan untuk menemukan hasil akhir (Kristin dan Rahayu, 2016). Siswa memahami benar bahan pelajaran, sebab mengalami sendiri proses menemukannya. Sesuatu yang diperoleh dengan cara ini lebih lama diingat, proses menemukan sendiri menimbulkan rasa puas siswa. Pembelajaran dengan penemuan mendorong siswa untuk belajar melalui keterlibatan secara aktif mereka sendiri dengan konsep-konsep dan prinsip-prinsip dan guru mendorong siswa untuk mengalami pengalaman yang memungkinkan mereka menemukan prinsip-prinsip untuk diri mereka sendiri (Hosnan, 2014). Dalam pelaksanaan model pembelajaran discovery aktivitas siswa belajar sendiri sangat berpengaruh dalam hasil belajar dengan model pembelajaran discovery (Krismanto, 2005). Dalam discovery learning kegiatan atau pembelajaran yang dirancang sedemikian rupa sehingga siswa dapat menemukan konsep-konsep dan prinsipprinsip melalui proses mentalnya sendiri. Hal ini sangat penting dalam meningkatkan hasil belajar siswa.

Literasi ekologi juga bersesuaian dengan karakteristik subak sebagai sumber belajar. Konsep subak mengacu pada filosofi dasarnya Tri Hita Karana, dimana secara praktis konsep palemahan tercermin pada teknologi dan lingkungan fisik (sawah dan ekologi air) (Sriartha et al., 2015). Dengan berlandaskan pada filosofi Tri Hita Karana, subak telah diakui perannya sangat efisien dan efektif dalam mengelola kelestarian sumberdaya pertanian, terutama air irigasi (Sriartha dan Windia, 2015). Komponen palemahan adalah perwujudan kearifan teknologi dan ekologi (Sriartha, 2014). Aspek penyusun yang tercakup dalam literasi ekologi adalah aspek pemahaman konsep ekologis, kepedulian dan sikap erat kaitannya dengan kearifan lokal subak yang ada di masyarakat. Adanya sistem subak merangsang peserta didik untuk berpartisipasi secara aktif terlibat dalam membangun bentuk pengetahuan, solusi, komunikasi, dan pengambilan keputusan (Surata dkk., 2014). Hal ini dapat meningkatkan pemahaman ekologi siswa dan kepedulian siswa terhadap kelestarian lingkungan serta dapat bersikap yang baik untuk mencegah kesusakan lingkungan. Dengan demikian, kearifan lokal subak sebagai sumber belajar dapat mengembangkan literasi ekologis dan hasil belajar siswa secara maksimal.

Berbeda dengan pembelajaran IPS dengan menggunakan pembelajaran konvensional, lebih menekankan pada fungsi guru sebagai pemberi informasi. Siswa hanya pasif mendengarkan penjelasan guru tanpa dilibatkan secara aktif dalam pembelajaran. Guru menjelaskan dari konsep, definisi, pengertian sampai pada contoh-contoh. Siswa baru terlibat jika ada soal yang diberikan oleh guru dan lebih bersifat hafalan. Kreatifitas siswa kurang berkembang, sehingga akan berakibat pada kurang maksimalnya hasil belajar siswa. Sebagai bentuk perbandingan, pembelajaran konvensional lebih didominasi oleh kegiatan guru untuk memberikan instruksi atau ceramah selama proses pembelajaran berlangsung. Hal ini jelas akan menempatkan siswa sebagai penerima informasi yang pasif dan hanya menerima informasi dari guru. Proses pembelajaran cenderung kurang didasarkan pada pengalaman siswa. Hal ini kurang memberikan kesempatan mengembangkan literasi ekologis dan hasil belajar IPS siswa. 
Secara empiris, hasil penelitian ini didukung oleh hasil penelitian terdahulu yang dilakukan oleh Maryama dkk. (2018) menunjukkan bahwa discovery learning meningkatkan pemahaman konsep ekologi siswa.Literasi lingkungan siswa SMA berdasarkan hasil penelitian angket attitude dan knowledge menunjukkan hasil yang baik, sehingga layak sebagai perangkat pembelajaran untuk meningkatkan literasi lingkungan. Penelitian yang dilakukan oleh Christy (2019) menunjukkan bahwa ada perbedaan yang signifikan hasil belajar IPS antara siswa yang belajar menggunakan model pembelajaran guideddiscovery learning dengan siswa yang belajar menggunakan model pembelajaran konvensional. Hasil juga menunjukkan model pembelajaran guideddiscovery learning lebih baik dibandingkan model pembelajaran konvensional dalam capaian hasil belajar IPS siswa.

Hasil penelitian seperti yang disebutkan di atas tampak bahwa model discovery learning berbantuan subak sebagai sumber belajar berpengaruh terhadap literasi ekologis dan hasil belajar IPS siswa. Dengan demikian dapat disimpulkan bahwa terdapat perbedaan yang signifikan literasi ekologis dan hasil belajar IPS secara simultan antara siswa yang belajar menggunakan model discovery learning berbantuan subak sebagai sumber belajar dengan siswa yang belajar menggunakan model pembelajaran konvensional pada siswa SMP Negeri 4 Singaraja terbukti secara teoretis dan empiris.

\section{SIMPULAN DAN SARAN}

Berdasarkan analisis data dan pembahasan seperti yang telah diuraikan pada bagian sebelumnya, dapat ditemukan beberapa hal, yaitu (1) terdapat perbedaan yang signifikan literasi ekologis antara siswa yang belajar menggunakan model discovery learning berbantuan subak sebagai sumber belajar dengan siswa yang belajar menggunakan model pembelajaran konvensional pada siswa SMP Negeri 4 Singaraja, (2) terdapat perbedaan yang signifikan hasil belajar IPS antara siswa yang belajar menggunakan model discovery learning berbantuan subak sebagai sumber belajar dengan siswa yang belajar menggunakan model pembelajaran konvensional pada siswa SMP Negeri 4 Singaraja, dan (3) terdapat perbedaan yang signifikan literasi ekologis dan hasil belajar IPS secara simultan antara siswa yang belajar menggunakan model discovery learning berbantuan subak sebagai sumber belajar dengan siswa yang belajar menggunakan model pembelajaran konvensional pada siswa SMP Negeri 4 Singaraja.

Berkenaan dengan hasil penelitian yang diperoleh, beberapa saran yang dapat diajukan adalah sebagai berikut. Pertama, terdapat kendala yang dihadapi misalnya membutuhkan waktu belajar yang lebih lama dibandingkan dengan model pembelajaran konvensional. Untuk mengurangi kelemahan tersebut diperlukan bantuan guru. Bantuan guru dapat dimulai dengan mengajukan beberapa pertanyaan dengan memberikan informasi secara singkat. Kedua, guru diharapkan dapat memvariasikan proses pembelajaran yang dilakukan di kelas dengan menerapkan model discovery learning berbantuan subak agar mampu mengembangkan literasi ekologis dan hasil belajarnya. Ketiga, penelitian lanjutan yang berkaitan dengan model discovery learning berbantuan subak sebagai sumber belajar dalam pembelajaran IPS perlu dilakukan dengan penggunaan variabel lain seperti pengetahuan awal, yang merupakan bagian yang tidak terpisahkan dari siswa perlu dikaji pengaruhnya terhadap pengembangan dan penerapan model discovery learning berbantuan subak sebagai sumber belajar serta dampaknya terhadap kualitas proses pembelajaran IPS.

\section{DAFTAR RUJUKAN}

Astawa, Ida Bagus Made. 2015. Pengembangan Bahan Ajar Geografi Berkearifan Lokal Suplemen dalam usaha mewujudkan Insan Berkearifanlingkungan pada Sekolah Menengah Atas (SMA) di Provinsi Bali. Seminar Nasional Riset Inovatif III, 33-39.

Bell, F. H. 1978. Teaching and Learning Mathematics in Scondary School. New York: Wm C Brown Company Publisher.

Bruner, J. S. 1961. The Act of Discovery. Harvard Educational Review, 31, 21-32. 
Hosnan. 2014. Pendekatan Saintifik dan Kontekstual dalam Pembelajaran Abad 21. Bogor: Ghalia Indonesia.

Krismanto, A. 2005. Beberapa Teknik, Model dan Strategi dalam Pembelajaran Matematika. Yogyakarta: PPPG Matematika.

Kristin, Firosalia dan Rahayu, Dwi. 2018. Pengaruh Penerapan Model Pembelajaran Discovery Learning terhadap Hasil Belajar IPS pada Siswa Kelas 4 SD. Scholaria, 6(1), 84-92.

Lewinsohn, Thomas M. 2014. Ecological Literacy and Beyond: Problem-Based Learning for Future Professionals. AMBIO A Journal of the Human Environment, 1-10.

Nugroho, Latif Agung, Prayitno, Baskoro Adi, dan Karyanto, Puguh. 2018. Efektivitas Model Pembelajaran Problem Based Learning terhadap Kemampuan Literasi Ekologi Siswa Kelas X Sekolah Menengah Atas. Jurnal Konseling dan Pendidikan, 6(1), 1-7.

Orr, D. W. 1992. Ecological Literacy: Education and Transition to A Postmodern World. Albany: SUNY Press.

Pitana, I Gde. 2007. Sosiologi Pariwisata. Yogyakarta: Andi.

Roestiyah, N. K. 2004. Strategi Belajar Mengajar. Jakarta: Rineka Cipta.

Rohani, Ahmad. 2004. Pengelolaan Pengajaran. Jakarta: PT. Rineka Cipta.

Rohim, F., Susanto, H. dan Ellianawati. 2012. Penerapan Model Discovery Terbimbing pada Pembelajaran Fisika untuk Meningkatkan Kemampuan Berpikir Kreatif. Unnes Physics Education Journal, 1(1),1-5.

Sriartha, I Putu. 2014. A Spatial Study of Subak System Sustainability Based on Tri Hita Karana In Badung Regency Bali Province. Dissertation (unpublised). Postgraduate Program Faculty of Geography Gadjah Mada University, Yogyakarta.

Sriartha, I Putu dan Giyarsih, Sri Rum. 2015. Spatial Zonation Model of Local Irrigation System Sustainability (A Case of Subak System in Bali). Indonesian Journal of Geography, 47(2), 142-150.

Sriartha, I Putu, Suratman, dan Giyarsih, Sri Rum. 2015. The Effect of Regional Development on The Sustainability of Local Irrigation System (A Case of Subak System in Badung Regency, Bali Province). Forum Geografi, 29(1), 31-40.

Sriartha, I Putu dan Windia, Wayan. 2015. Efektivitas Implementasi Kebijakan Pemerintah Daerah dalam Mengendalikan Alih Fungsi Lahan Sawah Subak: Studi Kasus di Kabupaten Badung, Bali. Jurnal Kajian Bali, 5(2), 327-346.

Sriartha, I Putu dan Kertih, I Wayan. 2019. Subak Local Wisdom as Social Studies Learning Source in Junior High School. Advances in Social Science, Education and Humanities Research, 438, 23-27.

Supriatna, Nana. 2017. Ecopedagogy Membangun Kecerdasan Ekologis dalam Pembelajaran IPS. Bandung: PT Remaja Rosdakarya.

Surata, S. P. K., Jayantini, G. A. R. S., dan Lansing, J. S. 2014. Exploring Community Capital of The Balinese Subak Cultural Heritage: A Content Analysis of Participatory Maps. International Journal of Technical Research and Applications, 2(7), 28-34.

Suryosubroto. 2002. Proses Belajar Mengajar Di Sekolah. Jakarta: Rineka Cipta.

Widyasrini, Ni Luh. 2015. Pengaruh Model Pembelajaran PBL (Problem Based Learning) Terhadap Pemahaman Konsep IPS dan Kemampuan Pemecahan Masalah Siswa Dalam Mata Pelajaran IPS Kelas VIII SMP N 3 Kubutambahan Tahun Pelajaran 2015/2016. Psychology. 